\title{
電場下における粒子濃縮挙動に関する実験的検討
}

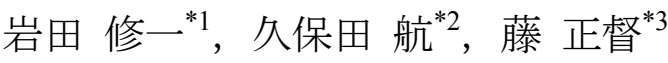 \\ 白井 孝 ${ }^{* 3}$, 南雲 亮 $^{*}$, 森 秀樹 ${ }^{* 4}$
}

\section{Experimental study of particle concentration under electric field}

\author{
Shuichi IWATA*1 ${ }^{*}$, Wataru KUBOTA ${ }^{* 2}$, Masayoshi FUJI ${ }^{* 3}$, Takashi SHIRAI ${ }^{* 3}$, Ryo NAGUMO*4 \\ and Hideki MORI ${ }^{* 4}$ \\ ${ }^{*} 1,{ }^{* 4}$ Depertment of Materials Science, Graduate School of Engineering, Nagoya Institute of Technology \\ Gokiso-cho, Showa-ku, Nagoya, Aichi 466-8555, Japan \\ ${ }^{* 2}$ Depertment of Life and Materials Engineering, Faculty of Engineering, Nagoya Institute of Technology \\ Gokiso-cho, Showa-ku, Nagoya, Aichi 466-8555, Japan \\ ${ }^{* 3}$ Advanced Ceramics Research Center, Nagoya Institute of Technology \\ 3-101-1 Honmachi, Tajimi, Gifu 507-0033, Japan
}

\section{Received 17 November 2014}

\begin{abstract}
It is difficult to remove well dispersed fine particles from dilute slurry, because filtration and evaporation process requires a lot of time and energy. Electrophoresis is known as a method of moving fine particles. Therefore, the electrophoresis technique is used to collect fine particles from such slurry as a paste of concentrated fine particles on electrodes. The viscous paste on the electrode is slowly falling down during electrophoresis process, finally drops from the electrode. This may affect recovery rate of the fine particles. In this paper, we studied transport phenomena of $5 \mathrm{wt} \%$ alumina slurry under electric field for producing the concentrated particles from the alumina slurry. The concentration rate of the particles is evaluated from weight of the concentrated particles. Time-dependent behavior of the concentration rate shows a good agreement with the theoretical approach. Since the alumina slurry is a power-law fluid, we applied shear between electrodes. The concentration rate of the particles is successfully enhanced due to decreasing in the apparent viscosity. In addition, we measured rheological properties of the concentrated particles.
\end{abstract}

Key words : Electrophoresis, Rheology, Fine particle, Particle concentration process, Recovering particles

\section{1. 緒言}

ナノテクノロジーの発展と共に，工業プロセスにおいてもナノ粒子を使うプロセスが多くなった．ナノ粒子を はじめとする微粒子は, 磁気的, 電気的, 化学的性質を示すことから, 幅広い分野での応用が期待されている（金 村, 2005)。一般に，粒子表面は，イオンの粒子表面と溶液への親和性が異なるため，粒子表面がイオン化され帯 電する．表面解離による帯電では，pH によって粒子の表面電位が変化する．粒子表面には，イオンが吸着して Stern 層が形成され，その周囲には静電引力と熱運動による拡散力とのバランスにより，拡散電気二重層が形成さ れる．電場の印加により，粒子が反対符号の電極に移動する電気泳動では，粒子とともに移動する分子とそれ以 外の分子とのすべりが生じるため，その位置における電位である電位が整理に用いられる（東谷, 1994, 1996). 電気泳動現象は, コロイド化学の世界では古くから研究されており, 多くの分析法の基礎となっている. また, 材料化学 的には電気泳動堆積法(electrophoretic deposition(EPD)) として知られている. この手法では粒子を電極表面に固

\footnotetext{
No.14-00611 [DOI:10.1299/transjsme.14-00611], J-STAGE Advance Publication date : 26 February, 2015]

${ }^{* 1}$ 正員, 名古屋工業大学大学院工学研究科物質工学専攻（广466-8555 愛知県名古屋市昭和区御器所町）

${ }^{* 2}$ 名古屋工業大学工学部生命・物質工学科

*3 名古屋工業大学先進セラミックス研究センター (†507-0033 岐阜県多治見市本町 3-101-1)

${ }^{* 4}$ 名古屋工業大学大学院工学研究科物質工学専攻

E-mail of corresponding author: iwa@nitech.ac.jp
} 
着・堆積し，コーティングすることが目的であり，電極表面上に粒子を凝集させるために，電位を等電点付近に 調節し, 粒子間の反発ポテンシャルが失われるように制御しなければならない（打越,目, 2000)。また, 電子部品 産業で用いられる Chemical Mechanical Polishing（CMP）では硬い微粒子を含むスラリーが研磨剤として用いられ ている.この CMP 用のスラリーは，高い分散性が求められ，粒子間の反発力を強くするために粒子の表面電位 を高くなるようにする必要がある，一方で，これら高分散性のナノ粒子を含む廃液処理については，粒子の体積 力が非常に小さいため, 重力沈降や遠心分離による分離は難しく, また, フィルター処理が困難な難濾過性物質 である. 蒸発乾固による方法では，エネルギー的に非効率かつ環境負荷の高いプロセスとなるため問題視されて いる（梅沢他, 2003）.

そこで本研究では, 微粒子が示す高い表面電位に着目した. 図 1 に示すように, 電気泳動により粒子を濃縮し, 電極近傍に粘度が増加したペースト状の非ニュートン性流体を作り，それを回収するというプロセスを想定し， そのプロセスに関する基礎的な検討を行う。また，電極近傍に集まるペーストの非ニュートン性に注目し，せん 断速度が濃縮速度におよぼす影響について検討した。
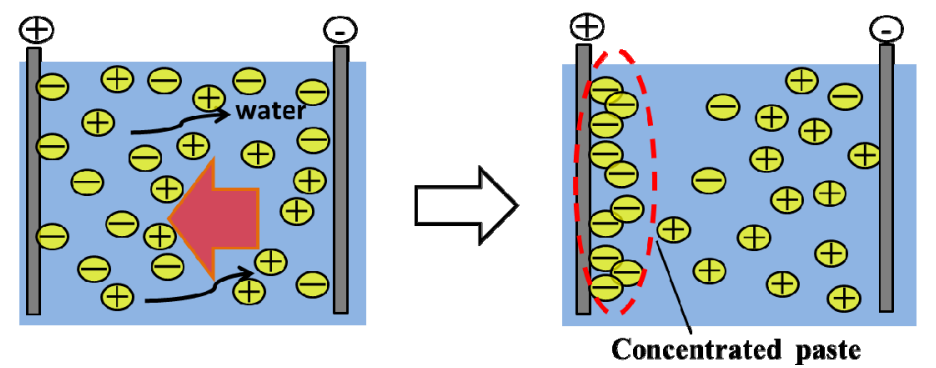

Fig.1 Image of concentrated particles. Fine particles with negative surface potential are moving anode under electric field, and forming a concentrated paste on the anode.

\section{2. 原理}

溶液中に分散している球形粒子の単位電場強度下での電気泳動移動度 $U\left[\mathrm{~m}^{2} /(\mathrm{s} \cdot \mathrm{V})\right]$ と 電位 $[\mathrm{V}]$ の関係は, 粒子半 径 $a[\mathrm{~m}]$ と電気二重層の厚み $(1 / \kappa)$ との関係で次式のように表すことができる. 単位電場あたりに移動する距離を示す電気 泳動移動度 $U$ は, 一般に,

$$
U=\frac{D \zeta}{6 \pi \eta} \times f(k a)
$$

と表される(Henry, 1931) (日本化学会, 1990). 分散媒の誘電率 $D[\mathrm{~F} / \mathrm{m}]$, 溶液の粘度 $\eta[\mathrm{Pa} \cdot \mathrm{s}]$ である. 補正項 $f(k a)$ はへン リー倸数であり, $k a$ に依存し, 1 から 1.5 の間をとる. $a$ が $1 / \kappa$ に比べて十分に大きいとき, $f(k a)=1.5$ と近似でき, 粒子の 電気泳動移動度 $U$ は次式となる(Nicholas, 1986)（化学工学会, 2005).

$$
U=\frac{D \zeta}{4 \pi \eta}
$$

これを Smoluchowski の式といら. 電位差 $V[\mathrm{~V}]$ と電極間距離を $\Delta x[\mathrm{~m}]$ とすると, 電位勾配 $E[\mathrm{~V} / \mathrm{m}]$ は $E=V / \Delta x$ であるので, 粒子の移動速度 $v_{p}[\mathrm{~m} / \mathrm{s}]$ は式(2) と合わせると, 次式が得られる。

$$
v_{p}=U E=\frac{D \zeta}{4 \pi \eta} \cdot \frac{V}{\Delta x}
$$

式(3)から, 粒子の移動速度は電位勾配 $V / \Delta x$, 粘度の逆数 $1 / \eta$ にそれぞれ比例することがわかる. しかし, 式(3) は溶 媒中の 1 つの粒子に着目した基礎式であり, 粒子が電極表面に濃縮された場合や, 電極近傍に流動が生じている場合 では, 帯電した粒子は近傍の粒子の相互作用を受けることが推察される.

ここで, 毛細管モデルを用いた電気浸透脱水に関する諸関係式を導出した駒形の研究(駒形, 1943)(吉田, 1987)を 紹介寸る. 電極近傍に不導体である粒子が多く存在する場合, 抵抗が大きくなり, 電流が流れにくくなる. 電極に堆積し た粒子の空隙を毛細管構造とみなして考えると, 液が一方から排出されるのみで他方から流入しない脱水過程だと考え られる. 比電導度 $\lambda_{l}[\mathrm{~S} / \mathrm{m}]$ の液が満たされた半径 $r_{c}[\mathrm{~m}]$ の毛細管の両端に一定電圧 $V_{0}[\mathrm{~V}]$ を印加すると, 電気浸透に 
よって液は一方から流出して, $t$ 時間後における脱水状態は図 2 のようになる. 液が一方から排出されるのみで 他方から流入しない脱水過程において, 印加電圧 $V_{0}$ の一部 $V[\mathrm{~V}]$ が電気浸透に関与して毛細管内の液が矢印の方 向に移動し，脱水後には等価比電導度 $\lambda_{e q}[\mathrm{~S} / \mathrm{m}]$ となる部分を残すとすれば，次のような関係式が成立する.

$$
\begin{aligned}
& V_{0}-V=\frac{l_{c}-l}{n \pi r_{c}^{2} \lambda_{e q}} i \\
& V=\frac{l}{n \pi r_{c}^{2} \lambda_{l}} i
\end{aligned}
$$

ここに, $n[-]$ は毛細管の数， $i[\mathrm{~A}]$ は，固体部分の電導性を無視したときに毛細管群内を流れる電流， $\alpha\left[\mathrm{m}^{2} /(\mathrm{V} \cdot \mathrm{s})\right]$ は, Helmholtz-Smoluchowski の電気浸透速度式より， $\alpha=D \zeta / 4 \pi \mu$ で定義される電気浸透度である. (4) (5) 式から, $i$ を消去して $l$ と $t$ との関係を表す次式を得る.

$$
l=\frac{\lambda_{l} l_{c}-\sqrt{\left(\lambda_{e q} l_{c}\right)^{2}+2 \lambda_{e q}\left(\lambda_{l}-\lambda_{e q}\right) \alpha V_{0} t}}{\lambda_{l}-\lambda_{e q}}
$$

粒子部分の導電性を無視した時に毛細管群内を流れる電流 $i[\mathrm{~A}]$ は, 式(4)〜(6)から, 次の式で表される.

$$
i=i_{0} / \sqrt{1+2\left(\frac{\lambda_{l}-\lambda_{e q}}{\lambda_{e q}}\right) \frac{t}{T}}
$$

ここに, $t$ は時間, $T$ は次式で示される.

$$
T=\frac{\Delta x}{D \zeta V / 4 \pi \eta \Delta x}
$$

このように, 電流 $i$ は $\sqrt{t}$ の関数で表される. 本研究では, 粒子の濃縮実験を行い, 濃縮量と濃縮時間から粒子濃縮挙動 の評価を行った.

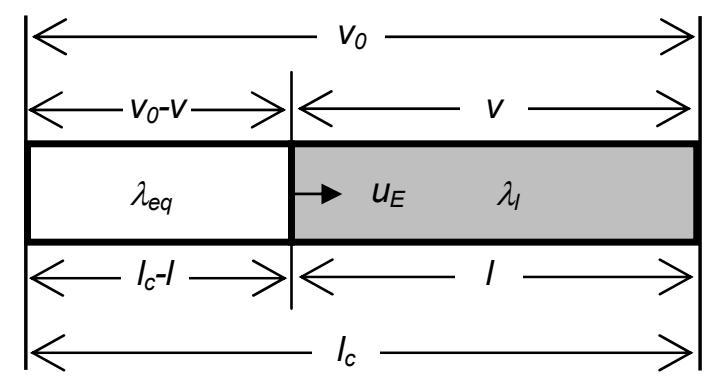

Fig.2 Schematic diagram of electroosmotic dewatering process based on straight capillary tubes model

\section{3. 実験試料の調整と実験方法}

\section{$3 \cdot 1$ 実験試料}

実験試料として $5 \mathrm{wt} \%$ アルミナスラリーを用いた. スラリーの調整方法は次の通りである. 蒸留水を分散媒とし, アルミナ 原料として昭和電工(株)製の AL-160SG-4 を用いた. また, 分散剤として, 主成分がポリカルボン酸である中京油脂(株) 製のセルナD-305をアルミナ粉末の重量に対して $0.9 \mathrm{wt} \%$ を加えた. ボールミルにて 24 時間粉砕した. 粒度分布測定装 置(MicrotracMT3200 II , 日機装(株) )により $5 \mathrm{wt} \%$ アルミナスラリーの粒度分布と平均粒子径を測定した. 粒度分布を図 3 に示寸. $120 \mathrm{~nm}$ 付近と $1 \mu \mathrm{m}$ 付近にピークを持つバイモーダルな分布を呈している. また, 平均粒径 $D_{50}$ は $220 \mathrm{~nm}$ あった.レオメータ(RS600, Haake Corp.)にて定常回転モードで $5 \mathrm{wt} \%$ アルミナスラリーのせん断粘度を測定した. 試料

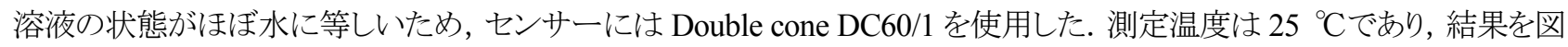
4 に示寸.このスラリーでは, べき乗則に従って, せん断速度の増加に伴い粘度は低下し, 溶媒の水の粘度で一定值を 
示した. また, 計測できた最も小さなせん断速度におけるせん断粘度は $2.89 \mathrm{~Pa} \cdot \mathrm{s}$ であった. 試料溶液の $\mathrm{pH}$ 測定にはポ ータブル pH メーター(SevenGo pH meter SG2, METTLER TOLEDO 製)を用いて測定し, ゼータ電位測定装置

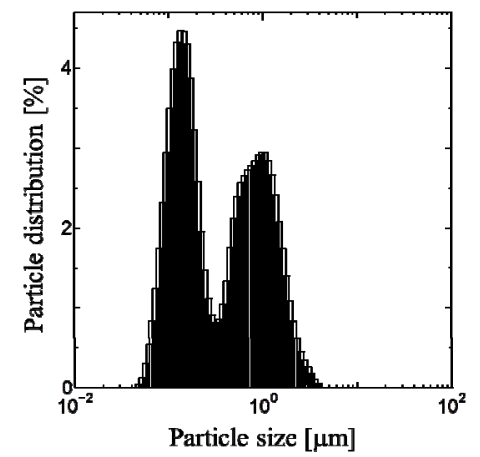

Fig.3 Particle distribution of $5 \mathrm{wt} \%$ alumina slurry

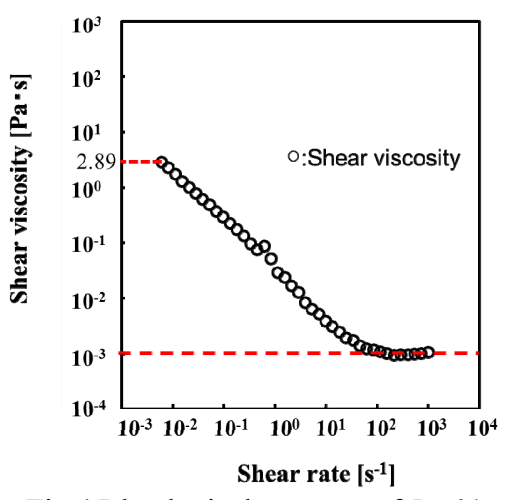

Fig.4 Rheological property of $5 \mathrm{wt} \%$ alumina slurry

(zetasizer nanoseries ZS, Malvern Instruments)を用いて 電位を測定した. pHは9.54であり，電位は-34.5 mVであった. 電位の絶対值が $30 \mathrm{mV}$ 以上では良好に分散することが知られており(古澤, 2004), 本研究で用いたアルミナ粒子は高 い分散性を示すことが分かる.

\section{$3 \cdot 2$ 粒子濃縮実験装置}

図 5 は静止場における実験装置図である. 試料溶液を入れるガラス容器は縦 $50 \mathrm{~mm} \times$ 横 $100 \mathrm{~mm} \times$ 高さ $70 \mathrm{~mm}$ であ り, 恒温槽 (Lab.VieW, TRW-70TP, アズワン(株)製) 内に容器を設置して行った. 電極は $25 \mathrm{~mm} \times 50 \mathrm{~mm}$ のステンレス 鋼板(SUS304)を用いた. 電極板の間隔を $\Delta x=20 \mathrm{~mm}$ とした. 図 6 に示寸ように, 電極板の角における電場の集中を防ぐ 為に, $20.0 \mathrm{~mm} \times 20.0 \mathrm{~mm}$ の空を持つ塩化ビニル樹脂製シールを張り付けた. 使用した塩化ビニル樹脂製シール(厚さ 0.11 mm, Craft ROBO, CR09016RD-380, グラフテック(株))をカッテイングマシン(Craft ROBO Pro, CE5000-40-CRP, グ
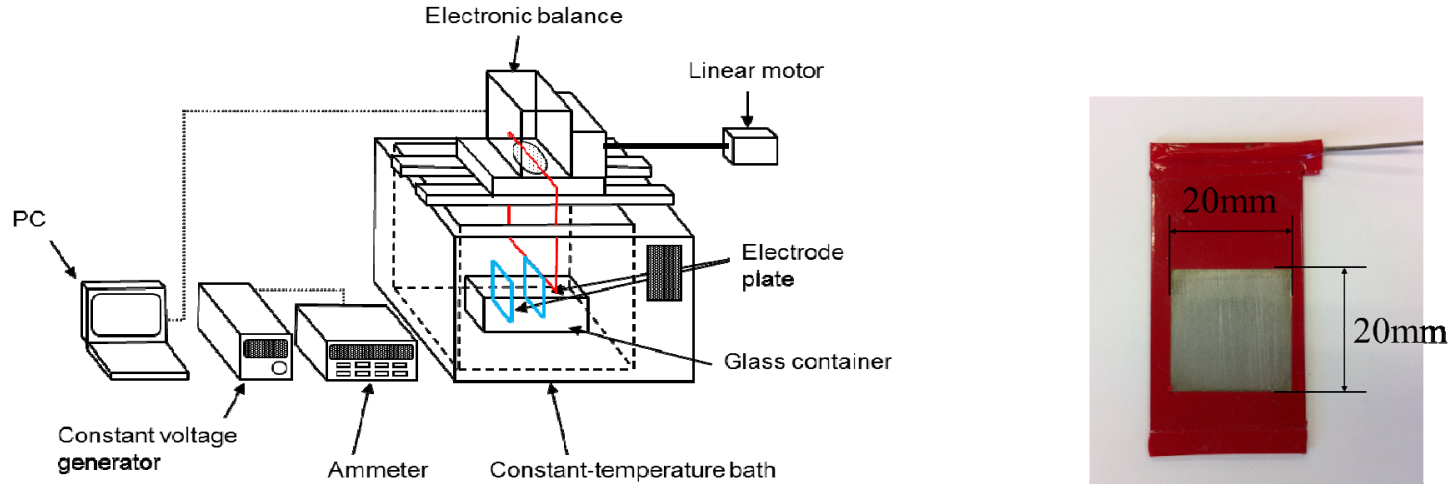

Fig.5 Schematic view of experimental apparatus

Fig.6 Close-up picture of anode electrode ラフテック(株)製)を用いて加工した. 電気泳動によるアルミナ粒子の濃縮量を測定する為に, 陽極側の電極を電子天秝

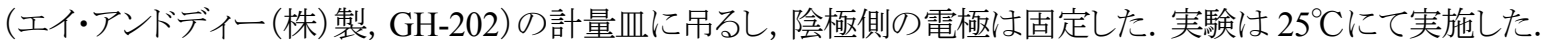

\section{$3 \cdot 3$ 濃縮粒子のレオロジ一測定装置}

図 7 は低せん断場における濃縮実験装置の写真である. 陽極には, 図6 と同じ電極を用いた. 負極には, 同様に塩化 ビニル樹脂製のシートを貼り付けたステンレス鋼板（SUS304）を用いたが, 陽極側に $20 \mathrm{~mm} \times 125 \mathrm{~mm}$ の空を持つ. 陽極 と陰極との間隔は $\Delta x=20 \mathrm{~mm}$ であり, リニアモーターにより, 陽極は陰極に対して平行移動することができる. 図 8 は, 濃縮 したペーストをその場測定するための装置図である.レオメータの上部センサーには, カップ状のセンサーを用い, 液に 接する面には塩化ビニル樹脂製のシートを貼り付け絶縁した. 上部センサー下面には直径 $50 \mathrm{~mm}$ の円形状にシートが 
切り取られており, その空の金属部分が電極として作動する. 一方, 下部センサーには, レオメータのパラレルプレート MP60 (直径 $60 \mathrm{~mm}$ ) のセンサー(222-1298, Haake Corp.)を用いた. 下部センサーの上面には, 直径 $50 \mathrm{~mm}$ の円形開口 部があり, その空の金属部分が電極として作動する. 下部センサーには, 内径 $D_{C}=68 \mathrm{~mm}$, 高さ $H=74.5 \mathrm{~mm}$ のテフロン

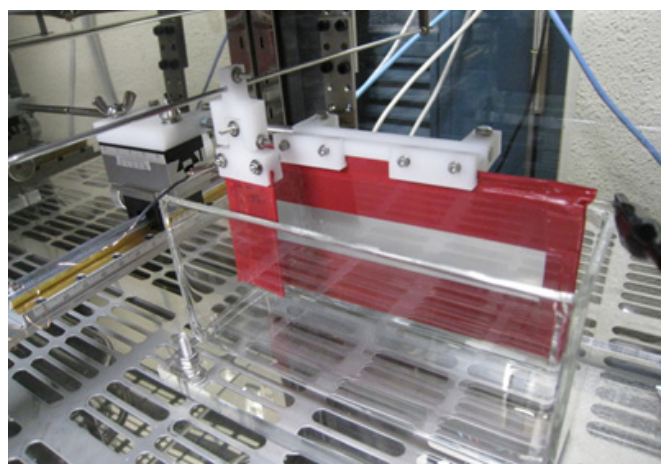

Fig.7 Experimental apparatus for measuring rate of particle concentration under lower shear field

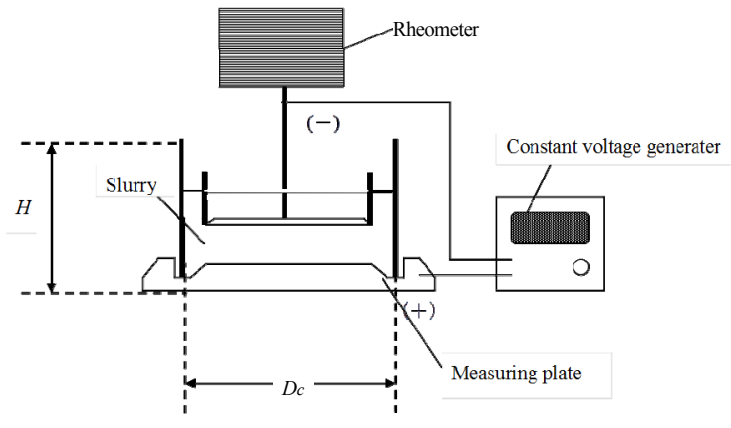

Fig.8 Viscosity measuring for the concentrated paste from alumina slurry

樹脂製カップが取り付けられており, $92 \mathrm{ml}$ のスラリーを入れることができる. 上部センサーと下部センサーは, それぞれレ オメータ本体と電気的に絶縁されており, 定電圧発生装置(VOAC7523, Iwatsu Corp.)により電場を印加した.

\section{4. 静止系における粒子濃縮挙動}

電場の印加によりアルミナ粒子が濃縮する速度を評価するために, 陽極側の電極近傍に濃縮されたペースト状の 重量の経時変化を測定する. 電極間距離を $\Delta x=20 \mathrm{~mm}$, 印加電圧を $V=20 \mathrm{~V}$ に設定した場合における陽極重量の時間変 化を図 9 に示す. 図中, 横軸は電圧の印加時間であり, 縦軸は, 電極近傍に濃縮した単位面積当りの電極重量の増加量 $W$ を表す. また, 直線は電圧印加から 300s 間, 曲線は 300s 後からの濃縮量を相関したものである. 電極表面では, 電圧 印加開始から約 5 分間は, 濃縮物の重量がほぼ一定速度で増加したが, 時間の経過に伴い, 増加速度が徐々に減少す ることがわかる.この現象については, 後で詳しく考察する. $t=660,780 \mathrm{~s}$ には増加速度の減少が認められ, $t=1020 \mathrm{~s}$ には 濃縮物の重量減少が確認された. 図 10 は, 実験後の電極表面の濃縮物である. 図中の破線部には, 濃縮されたペース 卜の一部の粒子が流下した痕跡が認められた.このことから, 増加速度の減少は, 電極から濃縮したアルミナ粒子が電極 板上で少しずつ流下し, 電極から落下したことが原因と考えられる. 次に, 洗瓶を用いて, 電極表面近傍に濃縮されたぺ 一ス卜状の粒子に噴射すると, 図 11 のように, 粒子は電極板から容易に流れ落ち, 金属光沢を持った電極表面が再び現 れた.このことから, 粒子は, 電極表面に堆積するのではなく, 濃縮された状態で電極近傍に分散していることが分かる.

次に, 図 9 における濃縮挙動では, 電場の印加直後から 300s 間においては, 濃縮物の重量は一定速度で増加したが, それ以降は増加速度が徐々に減少した. そこで, 電圧印加時間 $t$ における濃縮量 $W$ の定式化を試みる. まず, 式(3)より,

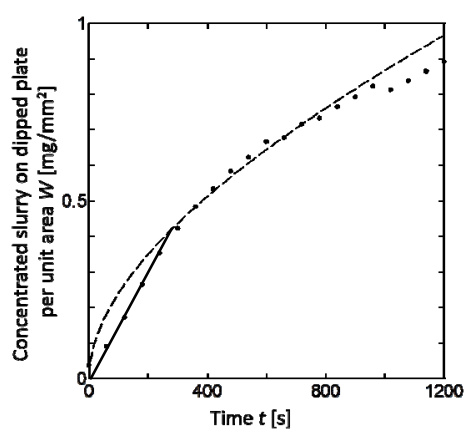

Fig.9 Accumulation of concentrated paste on the anode. For the first 5 minutes, accumulation of concentrated paste increases linearly (solid line). After 5 minutes, concentration rate decreases as a function of square root of time due to resistance in paste (broken line).
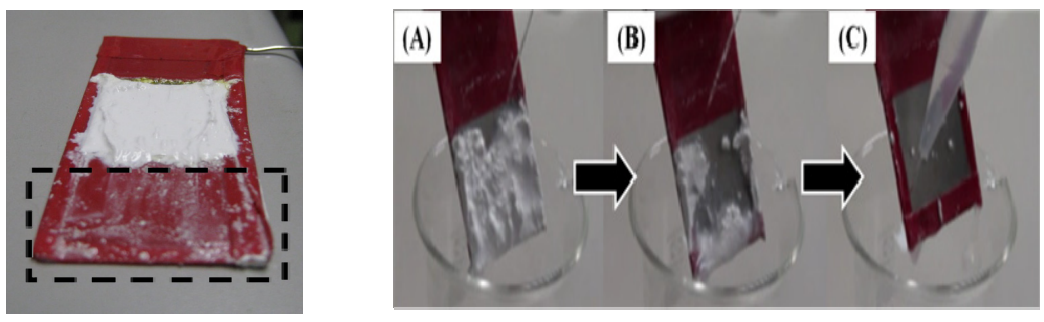

Fig.10 Concentrated paste on the anode electrode. It is revealed that concentrated paste flows down from a surrounded by broken line.
Fig.11 Rinse off the concentrated paste. It is easy to rinse off the concentrated paste and the glossy surface of electrode appears again. 
粒子の濃縮速度は電極間の電位勾配 $V / \Delta x$ に比例する. 本実験装置を用いた濃縮実験結果でも図 12 に示寸ように粒子 の移動流束 $q\left(=A v_{p}\right)$ はこの関係が得られた, この図の相関線からも粒子の濃縮量は印加電圧に比例していることが分か る. 電圧印加直後の 300s 間の領域では粒子が電場により移動したが, 電極近傍に存在する粒子は, 空隙率が大きな状 態で存在しており, 電気的な抵抗として大きな影響を与えないことが考えられる. 電極表面に濃縮された粒子の厚さを測 定し, その後に蒸発乾燥させることで, その時の粒子質量を測定し, 濃縮物の空隙率をを式(9)より算出した.

$$
\rho=(1-\varepsilon) \rho_{p}+\varepsilon \rho_{w}
$$

$\rho_{w}$ は溶媒の密度, $\rho_{p}$ は粒子の密度, $\rho$ は濃縮粒子の嵩密度である. この時点 $(t=300 \mathrm{~s})$ での空隙率は 0.424 であった. し かし, それ以降の時間では, 濃縮されたペースト内部で, 電場により粒子が電極に向かって移動し, 同時に粒子間を液 体が移動することにより, ペーストの空隙率が徐々に小さくなることが考えられる.ペースト状の濃縮粒子の空隙率は, $t=600,900,1200 \mathrm{~s}$ ではそれぞれ 0.366, 0.322, 0.282 であり, 徐々に減少した. 濾過操作におけるケーク脱水では, 電極 表面に不導体の粒子が濃縮されることにより, 抵抗が増加する(Shirato, et al., 1971) (吉田, 油川, 1987). これにより, ペ 一スト状の粒子の濃縮操作を長時間継続することは, ペースト部分に大きな抵抗を生み出すことになり, その部分には大 きな電圧降下が生じる. 図 1 に示すように, 一定電圧を印加して濃縮する場合では, ペース卜部の抵抗と溶液部の抵抗が 直列抵抗であり, 両者に電流 $i$ が流れる. 式(7)より, 電流 $i$ は時間 $t$ の平方根の関数として減少する. すなわち, 粒子濃 縮に利用可能な溶液部に印加される有効電位差 $V$ は, 溶液部の抵抗と電流 $i$ との積で表されることから, 時間 $t$ の平方根 の関数として減少する. よって, 移動速度 $v_{p}$ の積分量に相当する濃縮量 $W$ は時間 $t$ の平方根の関数として表されること が予想される. そこで, 濃縮量 $W$ と濃縮時間 $t$ との相関関係を調べるため, 濃縮量の実測值 $W_{\text {exp }}^{i}$ と, 相関式 $W_{c a l}^{i} \equiv b t^{m}$ を 用い, 次の目的関数 $\phi$ 分布を図 13 に示す.

$$
\phi \equiv \sum_{i}\left(\frac{W_{\exp }^{i}-W_{c a l}^{i}}{W_{c a l}^{i}}\right)^{2}
$$

ここに, 目的関数の評価には, $t=780 \mathrm{~s}$ までのデータを用いた. 図中の○印は目的関数が最小となった部分である.この 時の指数は $m=0.51$ であり, 濃縮量 $W$ はほぼ時間 $t$ の平方根の関数として表されることが分かった. 今回, 測定した電流 $i$ から抵抗を求め, 前述の最適化で得られた相関線を図 9 上に破線で示した. 濃縮挙動実験で得られた実験データとペ 一ス卜内部の濃縮の影響を受ける $300 \mathrm{~s}$ 以降の点における相関線からも濃縮量は時間 $t$ の平方根の関数として表されるこ とが分かる。

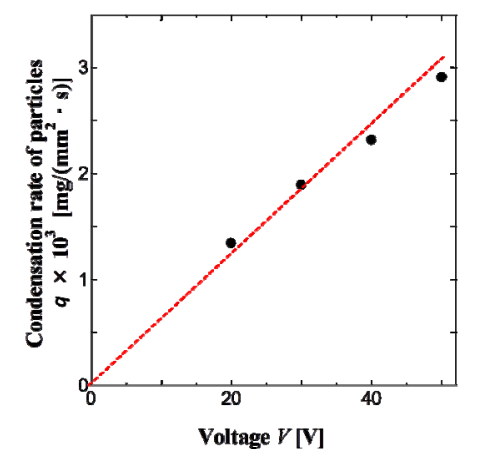

Fig.12 Effect of impressed electric field on concentration paste. Accumulation of concentration paste increases linearly as the applied voltage increases.

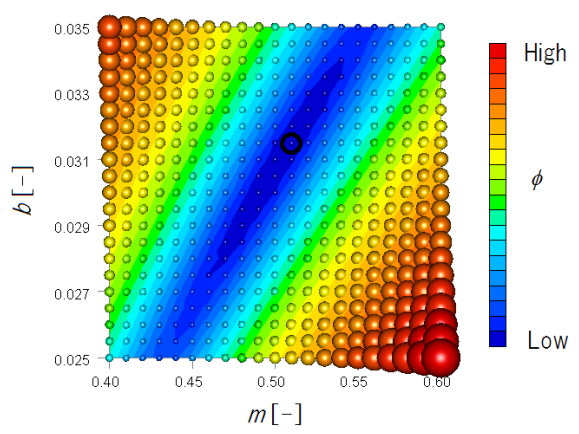

Fig. 13 Contour profile of the object function $\phi$. The circle plot means the optimum point. The optimum power index $(m=0.51)$ indicates that concentration rate decreases as a function of square root of time.

ペースト状に濃縮された粒子の粘度を測定するために, レオメータのセンサーを電極と見立てて静止場における濃 縮実験を行った. 初期状態におけるセンサーギャップを $20 \mathrm{~mm}$ に設定し, 印加電圧 $V=20 \mathrm{~V}$ の電場を $600 \mathrm{~s}$ だけ印加した. 電圧印加終了後には, ペースト状の粒子濃縮物がレオメータの下部センサーに厚さ $2 \mathrm{~mm}$ だけ付着した. 上澄み液を静 かに取り除き, センサーギャップが濃縮物の上面に接した $2.0 \mathrm{~mm}$ に設定し, ペースト状の濃縮物の粘度測定を行った. 図 14 は, 濃縮前の $5 \mathrm{wt} \%$ アルミナスラリーと濃縮後のペースト状濃縮粒子のせん断粘度分布である. センサー上に濃縮 
された粒子は, 樹脂製のスクレーパーで容易に掻き取ることができた. 濃縮前のスラリーとの比較より, 粘度は $10^{5}$ 倍ほど 大きくなり, 構造粘度指数はほぼ同じであることがわかった.

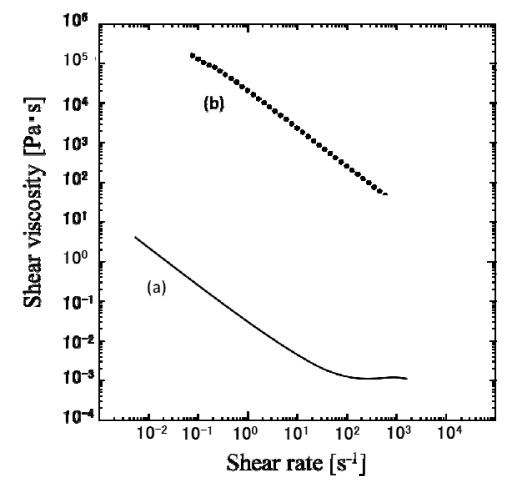

Fig.14 Rheological property of (a) Test slurry and (b) Concentrated paste. The viscosity of concentrated paste is about $10^{5}$ times as much as that of test slurry.

\section{5. 低せん断場における粒子濃縮速度への影響}

陽極を $0 \mathrm{~mm} / \mathrm{s} \sim 1.76 \mathrm{~mm} / \mathrm{s}$ の速度にて移動させ, 電極間にせん断を加えた条件にて粒子濃縮を行った. 濃縮時間と 濃縮量との関係を図 15 に示寸. 図中の各直線は実験結果から求めた近似直線である. せん断速度 $\dot{\gamma}$, 溶液のせん断粘 度 $\eta$ を静止場における粘度 $\eta_{0}$ で正規化した $\eta / \eta_{0}$, 濃縮速度を静止場における濃縮速度で正規化した濃縮速度 $q / q_{0}$ をそ れぞれ表 1 に示寸. 図 15 の濃縮速度の傾きに注目寸る. 電極移動速度が増加寸るにつれて, 粒子の濃縮速度は著しく 促進された. 図 3 の $5 \mathrm{wt} \%$ アルミナスラリーの粘度曲線に注目すると, 計測可能な最もせん断速度の低い時の粘度を静 止場 $\eta_{0}=2.89 \mathrm{~Pa} \cdot \mathrm{s}$ と見なした. 表 1 において, せん断速度が $0.045 \mathrm{~s}^{-1}$ では, 図 3 より試料溶液粘度は $0.481 \mathrm{~Pa} \cdot \mathrm{s}$ であり, 粘度が約 $1 / 5$ にまで低下寸る. 粒子の移動速度の基礎式(3)を考慮すると, 濃縮速度は約 5 倍に加速することが予想され る. 静止場の約 5 倍に加速された実験結果と, 粘度変化から予想された結果とが, ほぼ定量的に一致した. なお, 電極の 移動によって広範囲の粒子を集められる効果も指摘される. しかしながら, 例えば電極移動速度が $0.26 \mathrm{~mm} / \mathrm{s}$ の場合, 電 圧印加時間が $20 \mathrm{~s}$ 程度では, 電極面積の $1 / 4$ 程度しか水平に移動しない. ところが濃縮速度としては, 静止場における濃 縮速度のほぼ2倍であることから, 電極面の移動による効果よりも粘度減少効果の方が支配的であると考えられる. これら の結果より, 電極表面近傍に濃縮された状態にあるスラリーの粘度が, 電極の移動によって形成されたせん断場によって 減少し, 電極への粒子の移動速度が促進したことが考えられる.

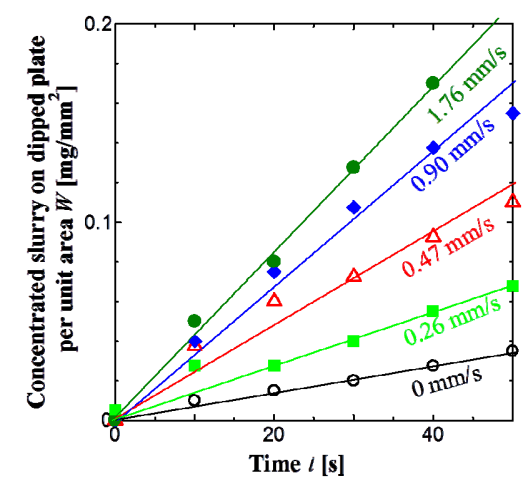

Fig.15 Effect of shear on accumulation of concentrated paste. The accumulation of concentrated paste increases as the shear rate increases.
Table 1 Effect of shear on particle concentration velocity. The inverse of viscosity ratio is almost the same as mass flux compared to static condition.

\begin{tabular}{|c|c|c|c|}
\hline $\begin{array}{c}\text { Sliding } \\
\text { velocity of } \\
\text { electrode } \\
{[\mathrm{mm} / \mathbf{s}]}\end{array}$ & $\begin{array}{c}\text { Shear } \\
\text { rate } \\
\dot{\gamma}\left[\mathbf{s}^{-1}\right]\end{array}$ & $\begin{array}{c}\text { Viscosity } \\
\text { ratio } \\
\eta / \eta_{0}[-]\end{array}$ & $\begin{array}{c}\text { Mass flux } \\
\text { compared to } \\
\text { static condition } \\
q / q_{0}[-]\end{array}$ \\
\hline 0.00 & 0.000 & 1 & 1 \\
\hline 0.26 & 0.013 & 0.448 & 2.06 \\
\hline 0.47 & 0.024 & 0.273 & 3.47 \\
\hline 0.90 & 0.045 & 0.167 & 5.16 \\
\hline 1.76 & 0.088 & 0.104 & 6.38 \\
\hline
\end{tabular}




\section{6. 結 言}

微粒子が示す高い表面電位に着目し，電気泳動により粒子を濃縮し，電極近傍に粘度が増加したペースト状の 濃縮物を回収するというプロセスを想定し, 微粒子の濃縮速度と, ペースト状の濃縮物について検討を行った. 静止 場における粒子の濃縮挙動より, 粒子の初期の濃縮速度は, 電極間の粒子の電気泳動が支配的であることが示された. その後, 電極表面近傍のペース卜内部で粒子の濃縮が進行することにより, ペースト部分に大きな抵抗が生じ, 粒子の濃 縮速度はほぼ時間 $t$ の平方根の関数として減少することが示された. また, 粒子の濃縮速度は, 電極間にせん断を印加 することにより, スラリーのみかけ粘度が低下することにより, 濃縮速度が向上寸ることが示された. 最後に, 電極上に濃 縮されたペースト状の粒子濃縮物についてその場粘度測定を行った. 濃縮前のスラリーとの比較より, 粘度は $10^{5}$ 倍ほど 大きくなり, 構造粘度指数はほぼ同じであることがわかった。

\section{謝 辞}

本研究の一部は, JST（平成 21 年度，平成 22 年度，A-STEP シーズ曊在化ステージ)，経済産業省（平成 26 年度「橋渡し研究事業（ものづくり中小企業・小規模事業者等連携事業創造促進事業）」）より行われた. 本実験 にご協力いただいた梅村亮介氏（元名古屋工業大学）に感謝する．記して謝意を表する.

\section{文献}

古澤邦夫, ゼータ電位の測定, ぶんせき, 日本分析化学会, Vol.9, No.5(2004), pp.247-254.

Henry, D.C., The cataphoresis of suspended particles. part I. the equation of cataphoresis, Proceeding of the Royal Society,

Vol.133, No.821(1931),pp.106-129.

東谷公, 化学工学会編, 化学工学の進歩 28,流体粒子系分離(1994), pp.33-37.

東谷公, 化学工学会編, 化学工学の進歩 30,微粒子制御(1996), pp.40-53.

金村聖志, 外部場を利用した新しいマテリアルプロセッシング, セラミックス, セラミックス協会編, Vol.40, No.3(2005),

pp.144-149.

駒形作次，電気浸透的脱水に就て，電気化学, Vol.11, No.3(1943), pp.83-86.

Nicholas, P.C., Encyclopedia of fluid mechanics: slurry flow technology, Gulf Publishing Co.(1986).

Shirato, M., Aragaki, T., Ichimura, K. and Ootsuji, N., Porosity variation in filter cake under constant-pressure filtration,

Journal of Chemical Engineering of Japan, Vol.4, No.2(1971), pp.172-177.

日本化学会編, 第 4 版実験化学講座, Vol.9 電気・磁気, 6 章 電気化学測定(1990), p.353.

化学工学会編, 改訂 6 版化学工学辞典(2005), p.252.

打越哲郎, 目義雄, 電気泳動法によるセラミックプロセッシングと水素吸蔵金属の利用, セラミックス, セラミックス協会編,

Vol.35, No.7(2000), pp.521-524.

梅沢浩之, 井関正博, 高岡大造, 対比地元之, 笹原辰巳, 浸漬型平膜ろ過による半導体 CMP 廃水処理システム,

SANYO TECHNICAL REVIEW, Vol.35, No.2(2003).

吉田裕志, 油川博, 低電圧条件における電気浸透脱水過程の解析, 化学工学論文集, Vol.13, No.4(1987),pp.466-473.

吉田裕志, スラッジの電気浸透脱水に関する研究, 名古屋大学博士論文(1987).

\section{References}

Furusawa, K., Measurement of zeta potential, Bunseki, The Japan Society for Analytical Chemistry, Vol.9, No.5(2004), pp.247-254 (in Japanese).

Henry, D.C., The cataphoresis of suspended particles. part I. the equation of cataphoresis, Proceedings of the Royal Society, Vol.133, No.821(1931), pp.106-129.

Higashitani, K., The Society of Chemical Engineers ed., The progress of chemical engineering 28 fluid-particle separation(1994), pp.33-47(in Japanese). 
Higashitani, K., The Society of Chemical Engineers ed., The progress of chemical engineering 30 particle control(1996), pp.40-53(in Japanese).

Kanamura, K., New material processing with external field, Ceramics, The Ceramic Society of Japan, Vol.40, No.3(2005), pp.144-149(in Japanese).

Komagata, S., Denkishintoutekidassuinitsuite(in Japanese),Denki Kagaku, Vol.11, No.3(1943), pp.83-86(in Japanese).

Nicholas, P.C., Encyclopedia of fluid mechanics: slurry flow technology, Gulf Publishing Co.(1986).

Shirato, M., Aragaki, T., Ichimura, K. and Ootsuji, N., Porosity variation in filter cake under constant-pressure filtration, Journal of Chemical Engineering of Japan, Vol.4, No.2(1971), pp.172-177.

The Chemical Society of Engineers ed., The forth series of experimental chemistry, Vol. 9 electricity $\cdot$ magnetism, Chapter 6 Electrochemical measurement(1990), p.353(in Japanese).

The Society of Chemical Engineers ed., The sixth series of chemical engineering dictionary(2005), p.252(in Japanese).

Uchikoshi, T. and Sakka, Y., Ceramics processing by electrophoretic deposition and utilisation of hydrogen absorbable metals, Ceramics, The Ceramic Society of Japan, Vol.35, No.7(2000), pp.521-524(in Japanese).

Umezawa, H., Iseki, M., Takaoka, D., Tsuihiji, M. and Kasahara, T., Wastewater treatment system for semiconductor process applied with immersed flat membrane filtration, SANYO TECHNICAL REVIEW, Vol.35, No.2 (2003)(in Japanese).

Yoshida, H. and Yukawa, H., Analysis of electroosmotic at constant voltage, Chemical Engineering papers, Vol.13, No.4 (1987),pp.466-473(in Japanese).

Yoshida, H., A study on the electro-osmotic dehydration of sludge, Doctoral thesis of Nagoya University(1987)(in Japanese). 